Article

\title{
Preparation of Fly Ash-Based Porous Ceramic with Alumina as the Pore-Forming Agent
}

\author{
Yulong Yang * ${ }^{(\mathbb{B}}$, Fengli Liu, Qibing Chang, Zhiwen Hu, Qikun Wang and Yongqing Wang \\ School of Materials Science and Engineering, Jingdezhen Ceramic Institute, Jingdezhen 333403, China; \\ liufengli@jci.edu.cn (F.L.); changqibin@jci.edu.cn (Q.C.); huzhiwen@jci.edu.cn (Z.H.); \\ wangqikun@jci.edu.cn (Q.W.); wangyongqing@jci.edu.cn (Y.W.) \\ * Correspondence: yyl0822@126.com; Tel.: +86-798-8461173
}

Received: 7 March 2019; Accepted: 10 April 2019; Published: 11 April 2019

\begin{abstract}
Low-cost porous ceramic from fly ash with alumina as the pore-forming agent was produced. The effect of the alumina content on line shrink, bulk density, mechanical strength, porosity, and phase composition of porous ceramic were investigated in detail. The results showed that the addition of alumina can help to improve the porosity and then it can change the pore structure of porous ceramic. Meanwhile, the addition of alumina can react with $\mathrm{SiO}_{2}$ in fly ash which can form the mullite. With the increase of alumina content, the content of quartz decreased gradually, while the alumina and mullite increased. Furthermore, the pore size becomes uniform and the permeability increased gradually. After sintering at $1250{ }^{\circ} \mathrm{C}$ for $0.5 \mathrm{~h}$, the porous ceramic has been obtained the bending strength of $\geq 35 \mathrm{MPa}$ and the porosity of $\geq 28 \%$ with the addition content of alumina ( $25 \mathrm{wt} \%$ ).
\end{abstract}

Keywords: porous ceramic; fly ash; alumina; porosity; bending strength

\section{Introduction}

As a kind of special function ceramics, porous ceramic has been widely used in the fields of gas and liquid filtration, purification, separation, thermal insulation and other sides with the advantages of their high porosity, high temperature resistance, good corrosion resistance, and high chemical stability [1-4]. Generally, porous ceramics are often prepared from $\mathrm{Al}_{2} \mathrm{O}_{3}[5], \mathrm{SiO}_{2}$ [6], $\mathrm{ZrO}_{2}$ [7], $\mathrm{TiO}_{2}$ [8], $\mathrm{SiC}$ [9], and their composite oxides [10] as the main raw materials. However, as the needs of some environment-related applications increases such as massive wastewater/waste-liquid treatment and low-cost catalysis-separation membrane and other fields, due to the higher cost of the raw materials, the use of porous ceramic has been limited [11]. Therefore, it is of great importance to develop low-cost fabrication techniques for porous ceramic. Currently, in order to reduce fabrication cost, several effective methods have been developed such as low-temperature sintering aids and the cheap cost of raw materials [12].

Fly ash as an abundant and cheap raw material; it is generated from the combustion process in coal power plants and it has caused serious environmental pollution [13]. Consequently, the products made from fly ash, and its cost of raw materials can be approximated as freight. Therefore, some studies on the comprehensive utilization of fly ash have resulted in various applications. For example, glass, glass-ceramics, porous ceramics and composite catalysts, due to the fly ash is rich in certain metal oxides such as $\mathrm{Al}_{2} \mathrm{O}_{3}$ and $\mathrm{SiO}_{2}$ [14]. Thus, the effective utilization of fly ash not only resolves a significant environmental issue, but also produces high value-added products. However, when it was found that the main components of fly ash are $\mathrm{Al}_{2} \mathrm{O}_{3}$ and $\mathrm{SiO}_{2}$, most researchers focused on the preparation of dense mullite $\left(3 \mathrm{Al}_{2} \mathrm{O}_{3} \cdot 2 \mathrm{SiO}_{2}\right)$ and its composites with addition of other aluminum sources, such as alumina [15], aluminum hydroxide [16], and bauxite [17,18]. Recently, some previous studies showed that fly ash is suitable for fabrication of porous mullite ceramics [19,20]. 
Traditionally, the porosity of the porous ceramic depends on the particle size distribution of the raw materials. At the same time, in order to increase the porosity, some pore-forming agents are used, which burn out during the sintering, such as carbon powder, fiber, wood chips, and starch [21,22]. However, the pores produced by this method caused a sharp reduction in bending strength. Thus, it is of great importance to find a way to produce high porosity without sharp decreasing in bending strength of porous ceramic [23], which is expected to withstand large pressure during practical applications.

In the present study, the fabrication of low-cost porous ceramic via the fly ash with alumina as the pore-forming agents has been reported. The study was carried out to understand the effect of the addition of alumina on the mechanical strength, phase composition, and permeability of the porous ceramic.

\section{Materials and Methods}

\subsection{Samples Preparation}

The fly ash used in this study comes from the power station of Jingdezhen. The most distinctive property of this fly ash and its high content of $\mathrm{SiO}_{2}$. The chemical composition of the fly ash powder were shown in Table 1 . Alumina $\left(\alpha-\mathrm{Al}_{2} \mathrm{O}_{3}\right)$ powders (Luoyang, He'nan, China, purity $\geq 99 \%$ ) were calcined and it used without further treatment, the median size $\left(\mathrm{d}_{50}\right)$ of the alumina powders is $8.2 \mu \mathrm{m}$, which is denoted as W10. The particle size distributions of the fly ash and alumina powders were shown in Figure 1.

Table 1. The chemical composition of fly ash by XRF.

\begin{tabular}{cccccccccccc}
\hline Component & $\mathrm{Al}_{2} \mathrm{O}_{3}$ & $\mathrm{SiO}_{2}$ & $\mathrm{Fe}_{2} \mathrm{O}_{3}$ & $\mathrm{CaO}$ & $\mathrm{MgO}$ & $\mathrm{K}_{2} \mathrm{O}$ & $\mathrm{Na}_{2} \mathrm{O}$ & $\mathrm{TiO}_{2}$ & $\mathbf{P}_{2} \mathrm{O}_{3}$ & $\mathrm{SO}_{3}$ & L.O.I \\
\hline $\begin{array}{c}\text { Content } \\
\text { (wt } \%)\end{array}$ & 37.12 & 55.39 & 3.25 & 1.78 & 1.26 & 2.83 & 0.18 & 1.1 & 0.19 & 0.19 & 6.71 \\
\hline
\end{tabular}

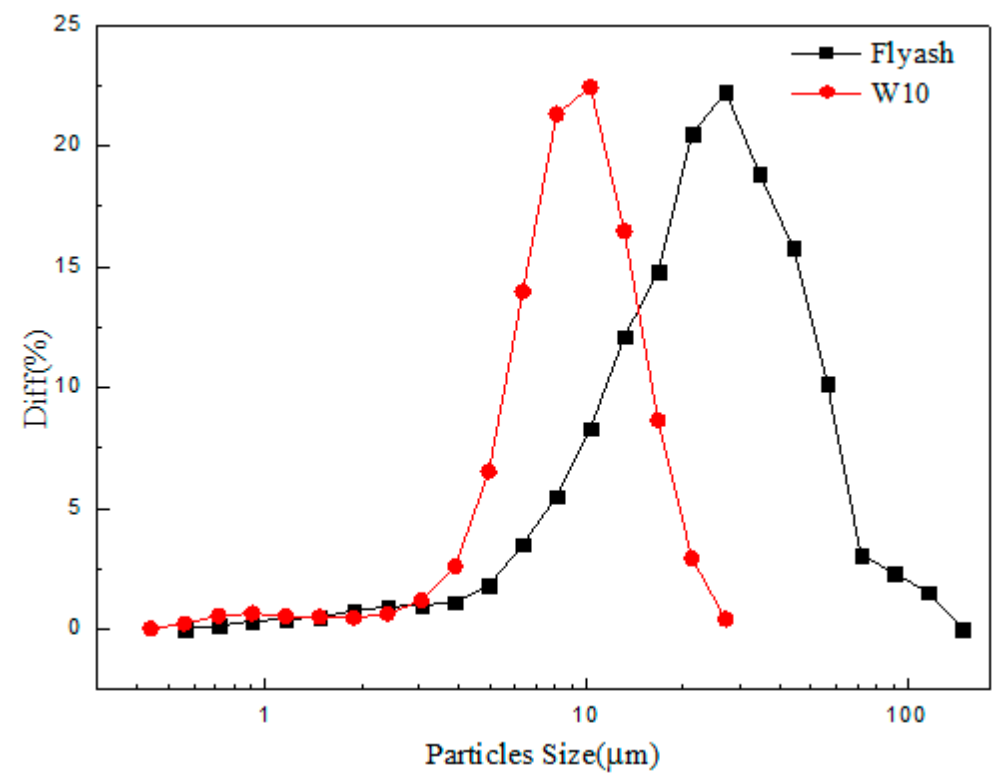

Figure 1. The particle size distribution of the fly ash and alumina.

The fly ash and alumina powders were mixed with a ball mill (UBE-F2/4L, Hunan Uibert Nanotechnology Co., Ltd. Hunan, China) at $150 \mathrm{rpm}$ for $2 \mathrm{~h}$ with different ratios of weight. In the ball milling, the mass ratio of powder/alumina ball/alcohol is 1:1:1.8, the alumina balls have a diameter of $2 \mathrm{~mm}$. The obtained suspension was dried in an oven at $70^{\circ} \mathrm{C}$ in air for overnight. The fly ash-alumina powders were shaped into the rectangular bars of $30 \mathrm{~mm} \times 9 \mathrm{~mm} \times 5 \mathrm{~mm}(1 \times \mathrm{h} \times \mathrm{w})$ by dry pressing $(12 \mathrm{MPa})$. The bars were finally sintered at $1250{ }^{\circ} \mathrm{C}$ for $0.5 \mathrm{~h}$ to form the fly ash-based porous ceramic. 


\subsection{Characterization}

The Particle size distribution of the powders was measured by a laser particle size analyzer (Bettersize2000, Dandong, China).

The chemical compositions of the fly ash were examined by an Axios-Advanced wavelength dispersive X-ray fluorescence spectrometer (Wdxrf, Panalytical Corporation, Almelo, Netherlands).

The linear shrinkage ratio of the samples after firing was determined by Equation (1):

$$
\text { Shrinkage }=[(\mathrm{L} 0-\mathrm{Lt}) / \mathrm{L} 0] \times 100 \%
$$

where L0 and Lt represent the lengths of green bodies and fired samples, respectively. Three samples were measured and the data were averaged as the linear shrinkage.

The bulk density and porosity were measured in distilled water using the Archimedes' replacement method. Three samples were measured and the data were averaged as the bulk density and porosity.

The pore size distribution of the sintered compacts was measured by Mercury Intrusion Porosimetry (Autopore IV9500, Micromeritics, GA, USA).

The bending strength was measured by the three-point bending method at room temperature using a universal material testing machine (WDW-30, Xi'an Letry Machine Testing Co. Ltd., Xi'an, China), with a span length of $20 \mathrm{~mm}$ and loading speed of $0.2 \mathrm{~mm} / \mathrm{min}$. Five samples were measured and the data were averaged as the bending strength.

The crystalline phases were characterized by X-ray diffraction (XRD) in a German D8-Advance diffractometer in the range $2 \theta$ of $5-70^{\circ}$ at a scanning speed of $0.04^{\circ} / \mathrm{min}$, using $\mathrm{Cu} \mathrm{K} \alpha$ radiation at $50 \mathrm{kV}$ and $30 \mathrm{~mA}$.

The fracture surfaces of the sintered porous ceramic were observed by means of Field Emitting Scanning Electron Microscope (FE-SEM, JSM-6700F, JEOL, Tokyo, Japan) equipped with an energy dispersive spectroscopy (EDS) system operating at an accelerating voltage of $5.0 \mathrm{kV}$ or $15 \mathrm{kV}$ (15 kV for EDS).

The water flux of the porous ceramic was tested in a cross-flow filtration apparatus. The apparatus were capable of operating at a variety of temperatures and pressures. During the test, the volume of the water with the permeated of the porous ceramic and the collection time were recorded. Three samples were measured and the data were averaged as the water flux.

\section{Results and Discussion}

\subsection{Effect of the Alumina Addition on the Bending Strength and Porosity of the Porous Ceramic}

Figure 2 shows the bulk density and linear shrinkage of porous ceramic with different ratios of fly ash and alumina. It can be seen from the Figure 2, with increasing the addition content of alumina $(0 \mathrm{wt} \%$ to $30 \mathrm{wt} \%)$, both the linear shrinkage and the bulk density of the porous ceramic decreased gradually. It is verified that the addition of alumina contributes to improve the porosity of the porous ceramic. It can be explained that alumina acts as the support in the fly ash and increases the distance between the ceramic particles. Consequently, the fly ash shrinks and the alumina does not during the porous ceramic sintering. As a result, with increasing the addition content of alumina, the shrinkage of porous ceramic decreased. 


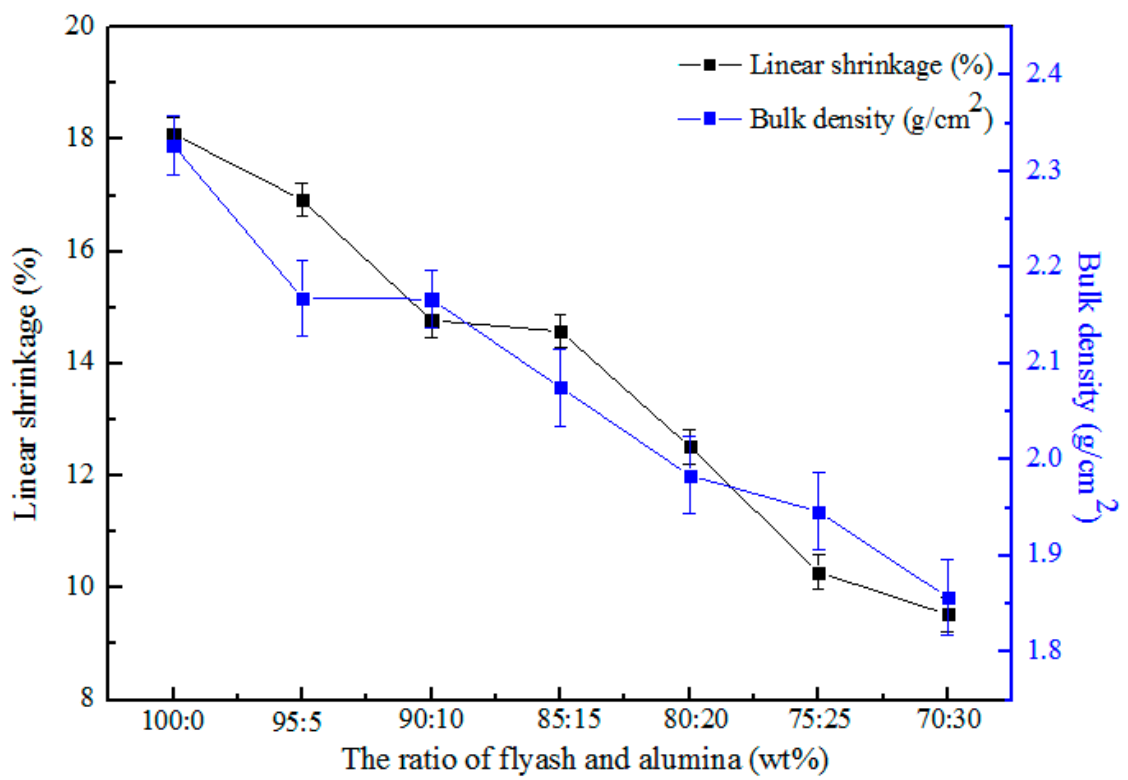

Figure 2. The Bulk density and linear shrinkage of porous ceramic with different ratio of fly ash and alumina at $1250{ }^{\circ} \mathrm{C}$ for $0.5 \mathrm{~h}$.

Figure 3 shows the bending strength and porosity with different ratios of fly ash and alumina. It can be seen from the Figure 3, the porosity of the porous ceramic increased gradually while increasing the addition content of the alumina. However, the bending strength of the porous ceramic decreased gradually. Generally, the mechanical properties of porous ceramic have been experimentally formularized as a function of porosity, which in quoted in [24]. Accordingly, the empirical relationship is given by the following equation:

$$
\sigma=\sigma_{0} \exp (-\beta \varepsilon)
$$

where $\sigma$ and $\sigma_{0}$ are the strengths of the ceramics and without pores, respectively. $\beta$ is the parameter determined by the nature of porosity, and $\varepsilon$ is the porosity. According to Equation (2), the strength of porous ceramic decreased exponentially with increasing the porosity.

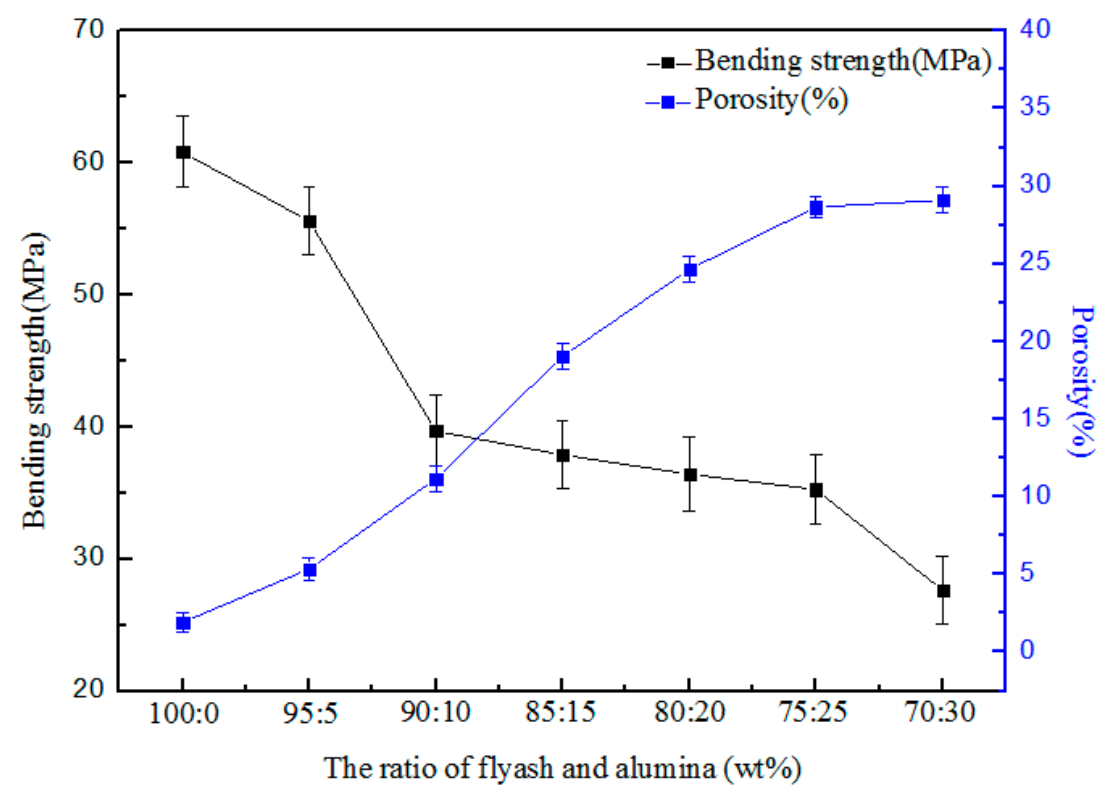

Figure 3. The bending strength and porosity of the porous ceramic with different ratio of fly ash and alumina at $1250{ }^{\circ} \mathrm{C}$ for $0.5 \mathrm{~h}$. 
The bending strength of the ceramic depends on the bonding area between the particles [25]. As discussed above, at the same sintered temperature, it was noted that a decrease of the density of porous ceramic and the bonding areas between ceramic particles while increasing the amount of alumina. As a result, the bending strength of the porous ceramic decreased and the porosity increased. According the Equation (2). Figure 4 shows the SEM images of the cross-section of porous ceramic with different ratios of fly ash and alumina. It can be seen from the A1 and B1, with increasing the addition content of alumina, the porosity of the porous ceramic increased. At the same time, as can be seen from the A2 and B2, the connection area of ceramic particles decreased and the bending strength decreased.
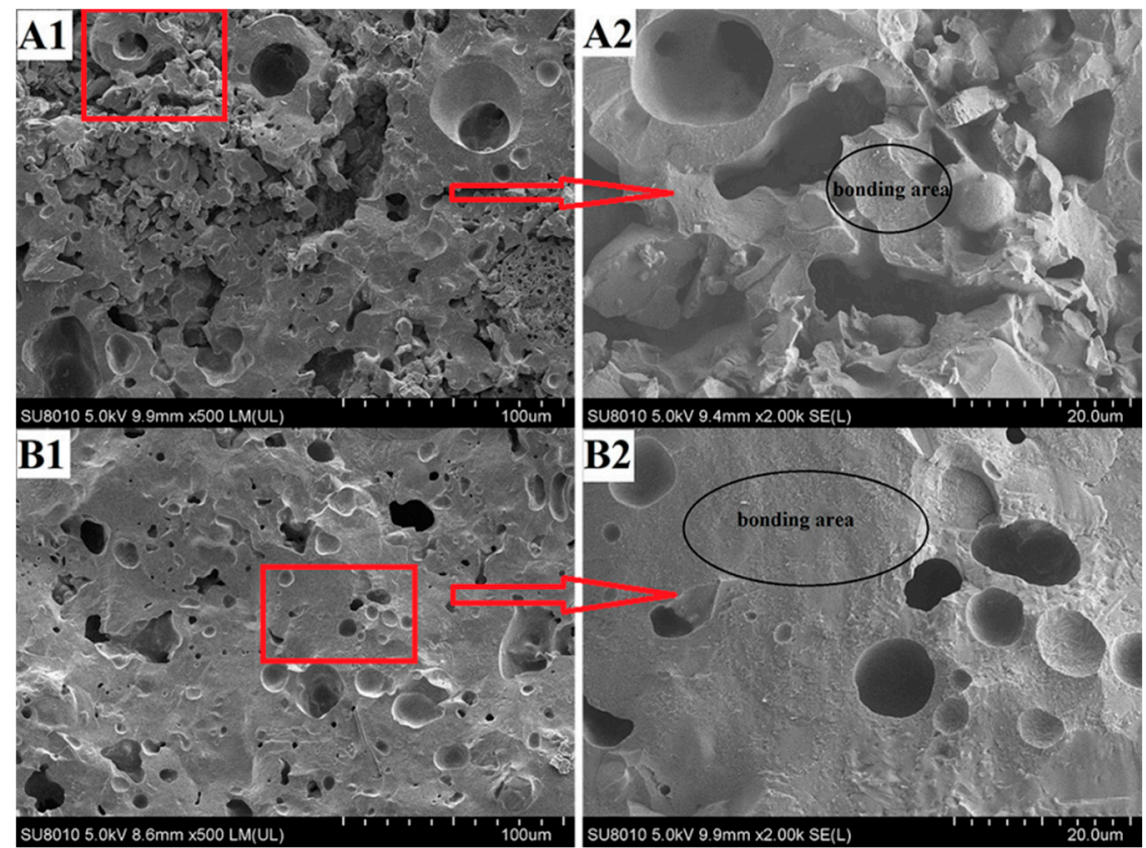

Figure 4. SEM images of the cross-section of porous ceramic with different ratio of fly ash and alumina; (A1) fly ash: alumina = 70:30; (A2) the local magnification of A1; (B1) fly ash: alumina = 100:0; (B2) the local magnification of B1.

It should be noted that when the addition content of alumina from $0 \mathrm{wt} \%$ to $10 \mathrm{wt} \%$ or from $25 \mathrm{wt} \%$ to $30 \mathrm{wt} \%$, the bending strength of the porous ceramic significantly decreased. However, when the addition content of alumina from $10 \mathrm{wt} \%$ to $25 \mathrm{wt} \%$, the bending strength of the ceramic decreased gradually. Meanwhile, the porosity of the porous ceramic increased. As shown in Figure 3, when the alumina content was $25 \mathrm{wt} \%$, the bending strength was $35 \mathrm{MPa}$ and the porosity was $28.65 \%$.

The physical properties of the porous ceramic are strongly related to the crystalline phase and microstructure. Thus, the EDS and XRD analyses are necessary. Figure 5 shows the EDS spectrum of the porous ceramic with the ratio of fly ash and alumina was 75:25. As can be seen, the EDS spectrum 1 displays the prismatic mullite crystals in the porous ceramic that they were consisted of $\mathrm{Al}_{2} \mathrm{O}_{3}$ and $\mathrm{SiO}_{2}$. In addition, the molar ratio $\mathrm{Al}_{2} \mathrm{O}_{3} / \mathrm{SiO}_{2}$ of the crystal was 1.57 , which is similar with the mullite $\left(\mathrm{Al}_{2} \mathrm{O}_{3} / \mathrm{SiO}_{2}=1.5\right.$ molar ratio). Therefore, the bending strength of the porous ceramic is greater because of the $\mathrm{Al}_{2} \mathrm{O}_{3}$ and $\mathrm{SiO}_{2}$ reacted to produce the mullite [14], which is also similar to the open literature [26]. The EDS spectrum 2 displays the alumina particles in the porous ceramic, and it is evenly distributed in the porous ceramic. The alumina acts as the support in the porous ceramic to further increase the porosity. What has been discussed above has been further verified: the addition of alumina contributes to the shrinkage decreasing and the porosity increasing. 

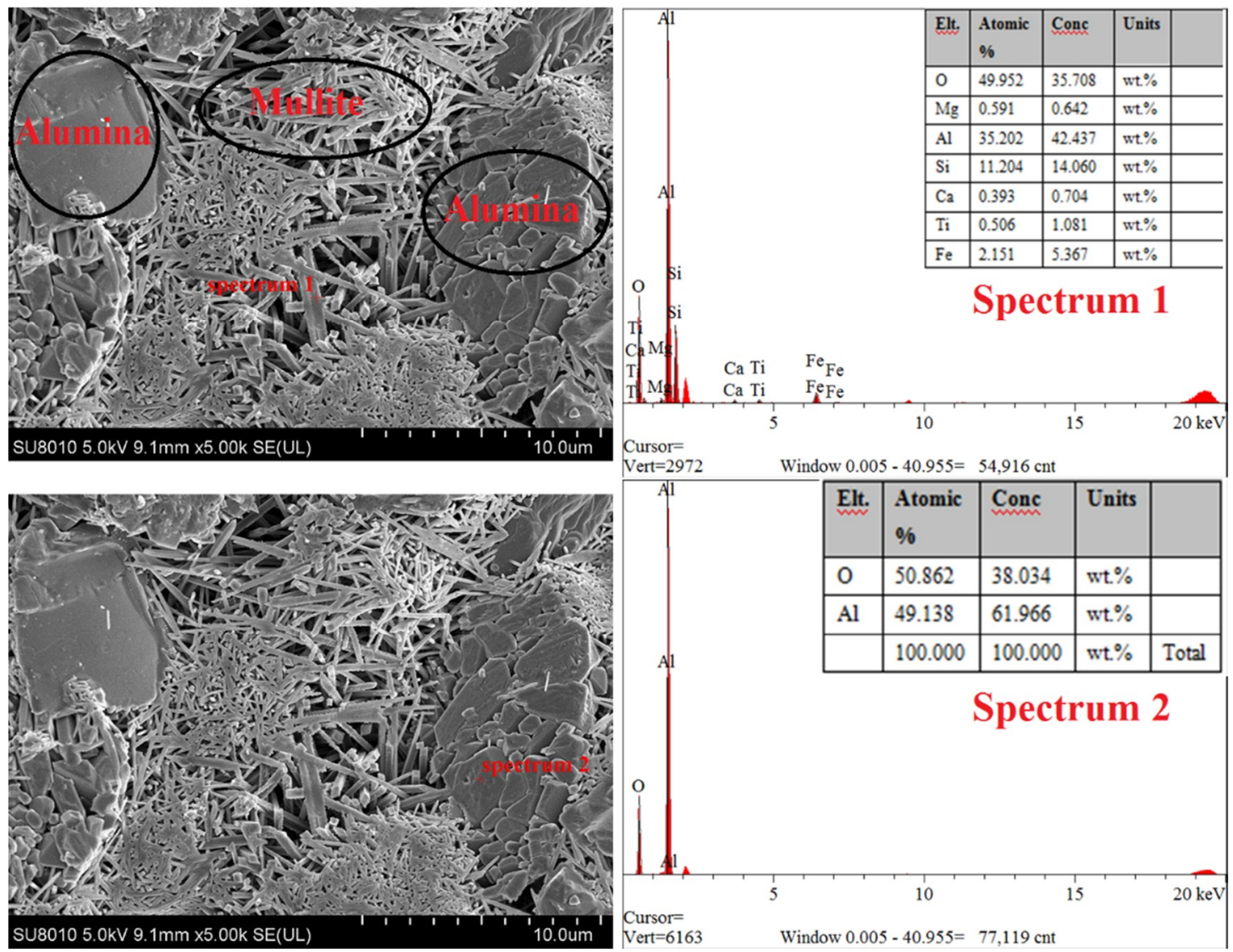

Figure 5. EDS spectrum of the porous ceramic with the ratio of fly ash and alumina was 75:25.

Figure 6 displays the XRD patterns of the different ratios of fly ash and alumina at $1250{ }^{\circ} \mathrm{C}$ for $0.5 \mathrm{~h}$. As can be seen, the ratio of fly ash to alumina was 100:0, the major crystalline phases are quartz and mullite. Meanwhile, there was a small content of alumina crystals in the fly ash. Therefore, the addition of alumina can reacts with fly ash to produce the mulite $\left(3 \mathrm{Al}_{2} \mathrm{O}_{3} \cdot 2 \mathrm{SiO}_{2}\right)$, and it can help to increase the bending strength of porous ceramic [27].

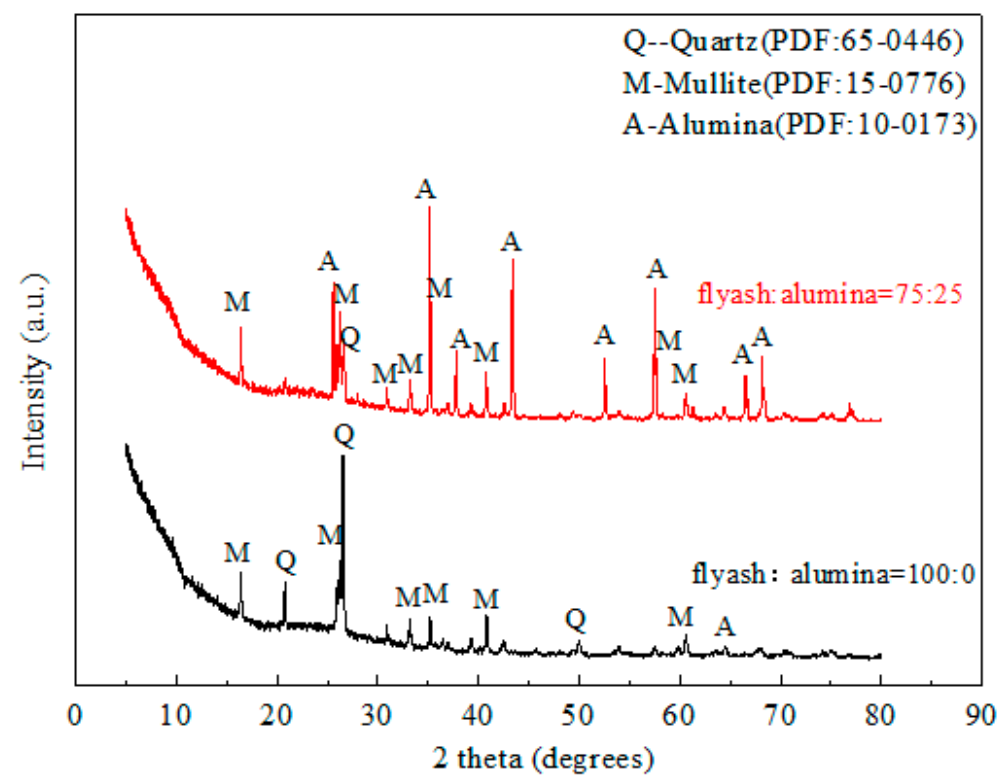

Figure 6. XRD patterns of the different ratio of fly ash and alumina at $1250{ }^{\circ} \mathrm{C}$ for $0.5 \mathrm{~h}$. 
The ratio of fly ash to alumina was 75:25. It can be seen that the quartz (PDF:65-0446) decreased compared with the ratio of fly ash to alumina was 100:0. At the same time, the mullite (PDF:15-0776) and alumina (PDF:10-0173) increased. It can be explained that the added alumina can increase the diffusion rate of $\mathrm{SiO}_{2}$, while it can be reacted with the silica to produce the mullite [28] during the sintering process. Moreover, it has an effect on the bending strength of the porous ceramic, which confirms what was discussed above (as shown in Figure 5).

\subsection{Effect of the Alumina Addition on the Pore Size Distribution of the Porous Ceramic}

The pore-size distribution of the porous ceramic depends on the particle size and the accumulation of the raw materials [29]. Figure 7 shown the pore size distribution of porous ceramic with different ratios of fly ash and alumina. According to the Figure 7, with increasing the addition amount of alumina, the pore size decreased gradually and the largest pore size also decreased. However, the pore-size distribution changes narrowly. It is reflected that the pores structure changes evenly. This is decided by the particle size distribution or composition of alumina and fly ash powders.

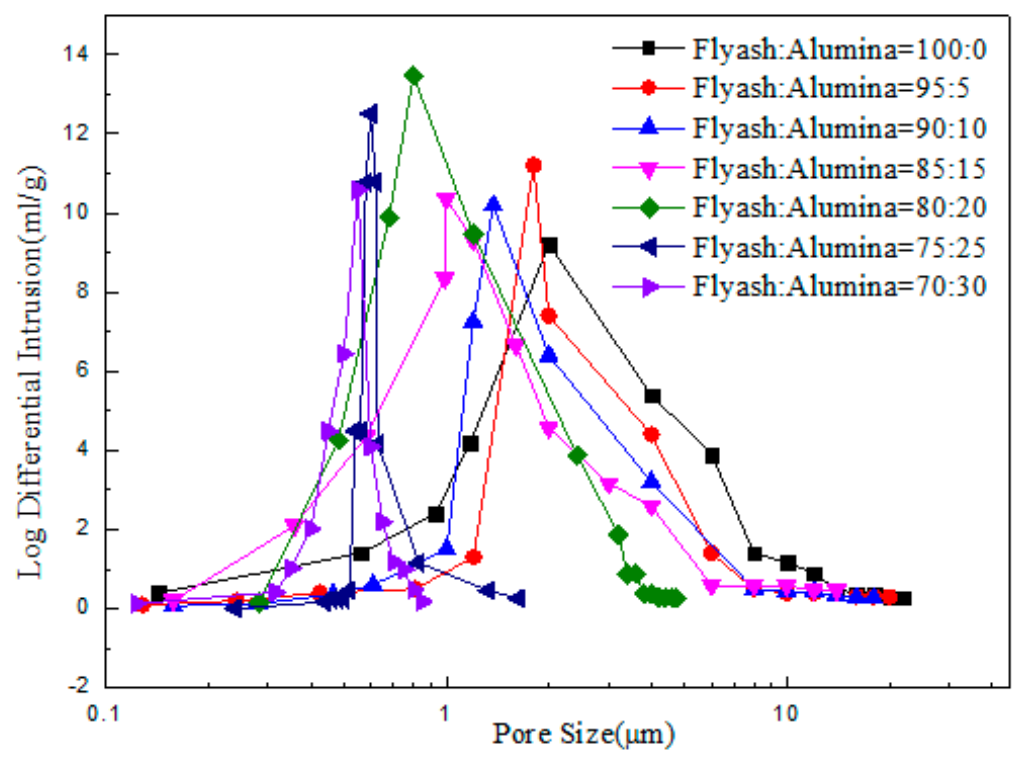

Figure 7. Pore-size distribution of porous ceramic with different ratio of fly ash and alumina.

There are two reasons for above results. On the one hand, the pores were formed because of the generation of gases [11] such as $\mathrm{CO}_{2}$ (from $\mathrm{Fe}_{2} \mathrm{O}_{3}, \mathrm{CaCO}_{3}$, and $\mathrm{MgCO}_{3}$ ) via the decomposition and some carbon particles burred in fly ash. Generally, these pores are larger and uneven, resulting in a larger average pore-size of porous ceramic. Accordingly, with increasing the addition content of alumina, these pores decreased gradually and the pore-size of porous ceramic decreased. On the other hand, the particle size distribution of the alumina are uniformly (as shown in Figure 1), and its own accumulation to formed the uniform pores.

\subsection{Effect of the Addition Content of Alumina on Permeability of the Porous Ceramic}

Figure 8 shows the water permeability of the porous ceramic with different ratios of fly ash and alumina. Obviously, the water permeability of the porous ceramic increased while increasing the addition content of alumina. This implies that the porous ceramic has a high permeating due to the low tortuosity and high porosity. 


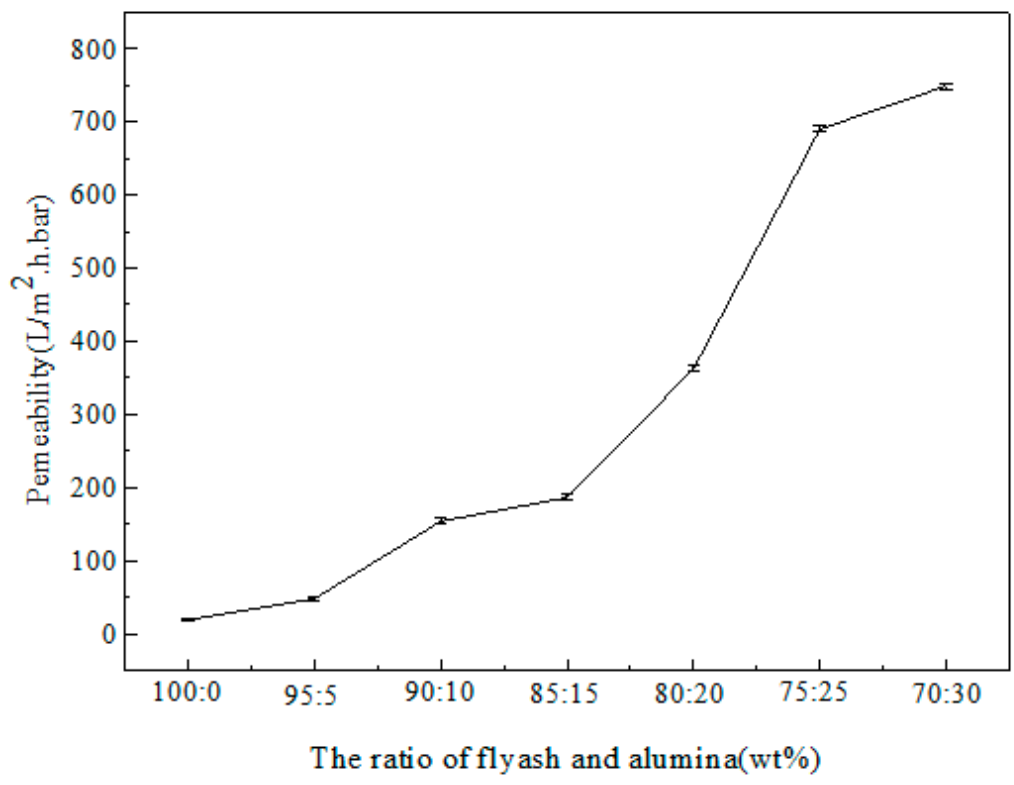

Figure 8. Water permeability of the porous ceramic with different ratio of fly ash and alumina.

The high alumina content may result in the high porosity due to the action of alumina although it may not provide the high bending strength. The even distribution of the alumina particles reduces the tortuosity with the pores of the porous ceramic. Both the high porosity and the low tortuosity improve the permeation according to the Hagen Poiseuille equation. Consequently, it is an effective method to prepare the porous ceramics by adding alumina as a pore-forming agent in fly ash.

\section{Conclusions}

Porous ceramic with excellent mechanical strength and high porosity were prepared from fly ash with alumina as the pore-forming agent. The addition content of alumina has an important effect on the property of porous ceramic. During the sintering process, the added alumina can increase the diffusion rate of $\mathrm{SiO}_{2}$ and react with it to produce mullite. Consequently, with increasing the content of alumina, the porosity of the porous ceramic increased. However, the bending strength acceptable. In addition, the pore-size distribution of porous ceramic becomes even and the pore-size decreased gradually. The porous ceramic has the porosity of $28.65 \%$ and the bending strength of $35 \mathrm{MPa}$ after sintering at $1250{ }^{\circ} \mathrm{C}$ for $0.5 \mathrm{~h}$ with the alumina content of $25 \mathrm{wt} \%$ added. This study identifies a cost-effective approach to porous ceramic materials from fly ash with alumina as the pore-forming agent.

Author Contributions: Y.Y. designed the experiments, analyzed the data, and wrote the paper. F.L. performed the experiments. Z.H. and Q.W. performed part of the experiments. Y.W. and Q.C. modified the grammar of the paper.

Funding: This work was supported by the National Natural Science Foundation of China (nos. 21761015, 51662020, and 51772136), Jiangxi Provincial Department of Science and Technology (no. 20165BCB19014), Education Department of Jiangxi Province (nos. GJJ170808 and GJJ170778), and Jingdezhen City Bureau of Science and Technology (no. 20161GYZD011-017).

Acknowledgments: The authors gratefully acknowledge the discussion of Jian-er Zhou.

Conflicts of Interest: The authors declare no conflict of interest.

\section{References}

1. Sarkar, S.; Bandyopadhyay, S.; Larbot, A.; Cerneaux, S. New clay-alumina porous capillary supports for filtration application. J. Membr. Sci. 2018, 392, 130-136. [CrossRef]

2. Shkrabina, R.A.; Boneckamp, B.; Pex, P.; Veringa, H.; Ismagilov, Z. Porous structure of alumina ceramic support for gas separation membranes, II. Study of porous structure of ceramic composition. React. Kinet. Catal. Lett. 1995, 54, 193-201. [CrossRef] 
3. Dong, Y.; Chen, S.; Zhang, X.; Yang, J.; Liu, X.; Meng, G. Fabrication and characterization of low cost tubular mineral-based ceramic membranes for micro-filtration from natural zeolite. J. Membr. Sci. 2006, 281, 592-599. [CrossRef]

4. Yan, W.; Li, N.; Han, B.; Liu, J.; Liu, G. Preparation and Characterization of Porous Cordierite Ceramics with Well-distributed Interconnected Pores. Trans. Indian Ceram. Soc. 2011, 70, 65-69. [CrossRef]

5. Ivanov, D.A.; Shlyapin, S.D.; Val'yano, G.E.; Fedorova, L.V. Structure and Physicomechanical Properties of Porous Ceramic Based on $\mathrm{Al}_{2} \mathrm{O}_{3}$ Prepared Using a Filtration Combustion Method. Refract. Ind. Ceram. 2018, 58, 538-541. [CrossRef]

6. Sun, Z.; Lu, C.; Fan, J.; Yuan, F. Porous silica ceramics with closed-cell structure prepared by inactive hollow spheres for heat insulation. J. Alloy. Compd. 2016, 662, 157-164. [CrossRef]

7. Han, J.; Hong, C.; Zhang, X.; Du, J.; Zhang, W. Highly Porous $\mathrm{ZrO}_{2}$ Ceramics Fabricated by a Camphene-Based Freeze-Casting Route: Microstructure and Properties. J. Eur. Ceram. Soc. 2010, 30, 53-60. [CrossRef]

8. Chen, J.; Liu, G.; Button, T.W. Mechanical properties of porous $\mathrm{TiO}_{2}$ ceramics fabricated by freeze casting process. Adv. Appl. Ceram. 2013, 112, 436-441. [CrossRef]

9. Shin, J.H.; Kumar, B.V.M.; Kim, J.H.; Hong, S.H. Tribological Properties of $\mathrm{Si}_{3} \mathrm{~N}_{4} / \mathrm{SiC}$ Nano-Nano Composite Ceramics. J. Am. Ceram. Soc. 2011, 94, 3683-3685. [CrossRef]

10. Chang, Q.B.; Liu, X.Q.; Wang, X.; Wang, Y.Q.; Zhou, J.E. Preparation of Porous $\mathrm{ZrO}_{2}-\mathrm{Al}_{2} \mathrm{O}_{3}$ Composite Ceramic with High Strength and Good Corrosion-Resistance. Adv. Mater. Res. 2011, 197, 1545-1548. [CrossRef]

11. Cao, J.; Dong, X.; Li, L.; Dong, Y.; Hampshire, S. Recycling of waste fly ash for production of porous mullite ceramic membrane supports with increased porosity. J. Eur. Ceram. Soc. 2014, 34, 3181-3194. [CrossRef]

12. Jiang, F.; Zhang, L.; Mukiza, E.; Qi, Z.; Cang, D. Formation mechanism of high apparent porosity ceramics prepared from fly ash cenosphere. J. Alloy. Compd. 2018, 749, 750-757. [CrossRef]

13. Jedidi, I.; Saïdi, S.; Khemakhem, S.; Larbot, A.; Elloumi-Ammar, N.; Fourati, A.; Charfi, A.; Salah, A.B.; Amar, R.B. Elaboration of new ceramic microfiltration membranes from mineral coal fly ash applied to waste water treatment. J. Hazard. Mater. 2009, 172, 152-158. [CrossRef]

14. Dong, Y.C.; Hampshire, S.; Zhou, J.E.; Ji, Z.; Wang, J.; Meng, G. Sintering and characterization of flyash-based mullite with MgO addition. J. Eur. Ceram. Soc. 2011, 31, 687-695. [CrossRef]

15. Jung, J.S.; Park, H.C.; Stevens, R. Mullite ceramics derived from coal fly ash. J. Mater. Sci. Lett. 2001, 20, 1089-1091. [CrossRef]

16. Li, S.; Du, H.; Guo, A.; Xu, H.; Yang, D. Preparation of self-reinforcement of porous mullite ceramics through in situ synthesis of mullite whisker in flyash body. Ceram. Int. 2012, 38, 1027-1032. [CrossRef]

17. Li, J.H.; Ma, H.W.; Huang, W.H. Effect of V2O5 on the properties of mullite ceramics synthesized from high-aluminum fly ash and bauxite. J. Hazard. Mater. 2009, 166, 1535-1539. [CrossRef] [PubMed]

18. Dong, Y.C.; Feng, X.; Feng, X.; Ding, Y.; Liu, X.; Meng, G. Preparation of low-cost mullite ceramics from natural bauxite and industrial waste fly ash. J. Alloy. Compd. 2008, 460, 599-606. [CrossRef]

19. Zhu, J.B.; Yan, H. Microstructure and properties of mullite-based porous ceramics produced from coal fly ash with added $\mathrm{Al}_{2} \mathrm{O}_{3}$. Int. J. Min. Met. Mater. 2017, 24, 309-315. [CrossRef]

20. Liu, X.R.; Xiong, L.; Chen, A.Y. Effect of Bentonite on Properties of Fly Ash-Based Porous Ceramics. Adv. Mater. Res. 2011, 412, 195-198. [CrossRef]

21. Živcová, Z.; Gregorová, E.; Pabst, W.; Smith, D.S.; Michot, A.; Poulier, C. Thermal conductivity of porous alumina ceramics prepared using starch as a pore-forming agent. J. Eur. Ceram. Soc. 2009, 29, 347-353. [CrossRef]

22. Jamaludin, A.R.; Kasim, S.R.; Abdullah, M.Z.; Ahmad, Z.A. Sago starch as binder and pore-forming agent for the fabrication of porcelain foam. Ceram. Int. 2014, 40, 4777-4784. [CrossRef]

23. Biesheuvel, P.M.; Verweij, H.; Biesheuvel, P. Design of ceramic membrane supports: permeability, tensile strength and stress. J. Membr. Sci. 1999, 156, 141-152. [CrossRef]

24. Knudsen, F.P. Dependence of Mechanical Strength of Brittle Polycrystalline Specimens on Porosity and Grain Size. J. Am. Ceram. Soc. 1959, 42, 376-387. [CrossRef]

25. Chang, Q.; Yang, Y.; Zhang, X.; Wang, Y.; Zhou, J.E.; Wang, X.; Cerneaux, S.; Zhu, L.; Dong, Y. Effect of particle size distribution of raw powders on pore size distribution and bending strength of $\mathrm{Al}_{2} \mathrm{O}_{3}$ microfiltration membrane supports. J. Eur. Ceram. Soc. 2014, 34, 3819-3825. [CrossRef] 
26. Wu, X.; Huo, Z.; Ren, Q.; Li, H.; Lin, F.; Wei, T. Preparation and characterization of ceramic proppants with low density and high strength using fly ash. J. Alloy. Compd. 2017, 702, 442-448. [CrossRef]

27. Zhang, Z.; Li, W.; Xie, W.; Liu, Y.; Du, G. Preparation of porous ceramic from fly ash and alumina. China Ceram. 2008, 44, 27-29. (In Chinese)

28. Lee, J.H.; Kim, W.Y.; Yang, T.Y.; Yoon, S.Y.; Kim, B.K.; Park, H.C. Fabrication of porous ceramic composites with improved compressive strength from coal fly ash. Adv. Appl. Ceram. 2011, 110, 244-250. [CrossRef]

29. Zhou, J.E.; Yang, Y.L.; Chang, Q.B.; Wang, Y.Q.; Yang, K.; Bao, Q.F. Effect of particle size gradients of alumina powders on the pore size distribution and bending strength of ceramic membrane supports. J. Synth. Cryst. 2014, 43, 2125-2131. (In Chinese)

(C) 2019 by the authors. Licensee MDPI, Basel, Switzerland. This article is an open access article distributed under the terms and conditions of the Creative Commons Attribution (CC BY) license (http://creativecommons.org/licenses/by/4.0/). 